\title{
Potentiodynamical Research of Zn-Al-Mg Alloy System in the Neutral Ambience of NaCl Electrolyte and Influence of Mg on the Structure
}

\author{
Reza Amini ${ }^{1}$, Ziadolla Obidov², Izatulla Ganiev $^{2}$, Mohammad Razazi ${ }^{1}$ \\ ${ }^{1}$ Department of Material Science and Engineering, Islamic Azad University, Majlesi Branch, Isfahan, Iran; ${ }^{2}$ Tajikistan Academy of \\ Sciences, Chemistry Institute, Dushanbe, Tajikistan. \\ Email: reza.amini@mail.ru
}

Received October $24^{\text {th }}, 2011$; revised December $3^{\text {rd }}, 2011$; accepted February $25^{\text {th }}, 2012$

\begin{abstract}
The results of anodic behavior of $\mathrm{Zn} 5 \mathrm{Al}, \mathrm{Zn} 55 \mathrm{Al}$ alloys alloyed with Magnesium in the environment and their microstructures are studied. A potentiodynamical research carried out by Zinc-Aluminum alloys, alloyed with Magnesium obtained a corrosion-resistant coating with optimum concentration of Magnesium about $0.005-0.1 \mathrm{wt} \%$. The rate of corrosion of these alloys is $2-2.5$ times lower than $\mathrm{Zn} 5 \mathrm{Al}, \mathrm{Zn} 55 \mathrm{Al}$ initial alloys. It is explained by the effect of modification on the structure of original alloys and they can be used as an anticorrosion coating for protecting corrosion of steel frames.
\end{abstract}

Keywords: Zn5Al; Zn55Al; Magnesium; NaCl Electrolyte; Corrosion Resistant

\section{Introduction}

Rapid growth in manufactured metal is accompanied by rapid growth in economic losses due to corrosion attack. The urgency of protecting metals against the corrosion is one of the oldest technical problems. It begins with the selection of material to generate products. Requirements for corrosion resistance of materials widely depend on the destination of the product, conditions of the working and the life of designed service. Products and structures which are made of metal. They are the most significant and valuable part of the fixed assets of any industrialized country and their protection from corrosion is a major problem. For these industries, corrosion resistance or chemical resistance of structural materials is one of the most important, and often the most vital characteristic that determines the reliability and service life of process equipment [1].

At present, almost, there is a large deficit in the non-ferrous metals in all industrialized countries. The most widely used metallic coating for the protection of corrosion of metals is Zinc (galvanize). It offers a very good combination of galvanic and barrier protection. Its excellent performance for many applications is well documented [2]. However, in the desire to improve, there is always a quest to find even better products. Researchers continually attempt to develop superior metal coatings that can be commercially applied. Often, the target is to find better products for specific end uses or environments, e.g. one is having superior corrosion resistance, or better coating formability. These attempts have met with little success most of the time, due either to an undesirable product attribute, or because manufacturing is too expensive and difficult [3]. In connection with making new alloys and introducing them into the technique, using of Zinc-Aluminum and their increased alloys especially in destructive environments which improves the corrosion resistance becomes relevant $[4,5]$.

Although the literature on the protective materials of corrosion for natural weathering conditions is quite large, much less is known on the $\mathrm{Zn}-55 \mathrm{Al}$ (e.g. Galvalume) and $\mathrm{Zn}-5 \mathrm{Al}$ (e.g. Galfan) used for the building applications. It is generally accepted that these coatings performed better in marine and industrial atmospheres than hot-dip galvanised coatings with regards to general corrosion protection [6].

The research dedicated to study the influence of additive Magnesium on the anodic behavior of $\mathrm{Zn} 5 \mathrm{Al}$ and $\mathrm{Zn} 55 \mathrm{Al}$ alloys and their microstructures which designed for applying protective coatings in hot methods.

\section{Experimental Procedure}

Raw materials, which are used in the research are Aluminum A7 grade, granular Zinc C.D.A grade, and granular pure Magnesium. These alloys were obtained in cru- 
cibles, which made of Aluminum oxide in a shaft furnace of CSHOL model in the temperature range of about $750^{\circ} \mathrm{C}-850^{\circ} \mathrm{C}$. Alloys were casted in a graphite mold with a diameter of 8 and $140 \mathrm{~mm}$. Non-operating parts of samples were isolated with a resin (a mixture of 50\% rosin and 50\% paraffin). Ends of the working parts were cleaned out with sandpaper, polishing, degreasing and were etched in $10 \%$ solution of $\mathrm{NaOH}$. They were washed thoroughly with alcohol and then immersed in a solution of $\mathrm{NaCl}$. The temperature of solution in the cell was maintained constantly $\left(20^{\circ} \mathrm{C}\right)$ with a MLSH- 8 thermostat. Reference electrodes were a saturated silver chloride with a subsidiary-Pt.

The anodic behavior of $\mathrm{Zn} 5 \mathrm{Al}$ and $\mathrm{Zn} 55 \mathrm{Al}$ alloyed with Magnesium was carried out in $\mathrm{NaCl}$ electrolytes with concentrations of $0.03 \%, 0.3 \%$ and $3 \%$ in PI-50.1.1, potentiostat with a $2 \mathrm{mV} / \mathrm{sec}$ potential velocity by the method which Ganiev has described [7]. Current-free potential set under submerging in electrochemical studies of anodic polarized potentiodynamic samples before a sharp increase in current because of pitting formation. then samples were polarized in the opposite direction to the potential of $1400 \mathrm{mV}$ and passive electrode layers were made consequently. Finally, the samples were polarized again in a positive direction. Extrapolation of the cathodic curve was conducted to $-1.600--1.800 \mathrm{~V}$ potential. The current corrosion density was carried out to a main electrochemical process of corrosion, which was determined by the cathodic curve that was taken to the tofely straight line is equal to $b_{\kappa}=0.124 \mathrm{~V}$ [8]. As an example, Figure 1 shows the potentiodynamic polarization curve of the $\mathrm{Zn} 55 \mathrm{Al}$ alloy, which was alloyed with $0.05 \mathrm{wt} \%$ of additive Magnesium. Calculation of the current corrosion density (i, A/ $\mathrm{m}^{2}$ ) was carried out by the following equations:

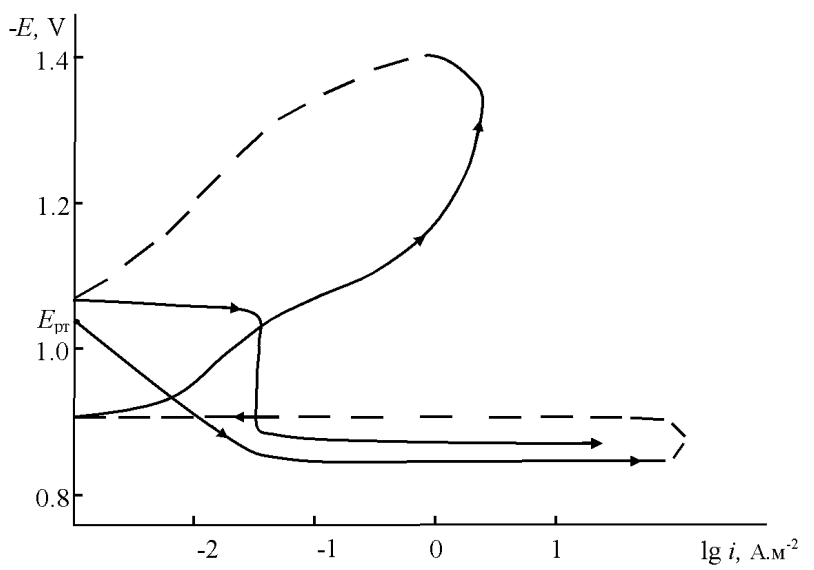

Figure 1. Potentiodynamic polarization curve of the Zn55Al alloy which contains of 0.05 wt \% Magnesium in $3 \%$ solution of $\mathrm{NaCl}$. E-potential $(\mathrm{V})$, $\mathrm{i}-$ current density $\left(\mathrm{A} \cdot \mathrm{m}^{-2}\right)$.

$$
\mathrm{S}=\pi \mathrm{r}^{2} ; \quad \mathrm{i}=\mathrm{I} / \mathrm{S}
$$

where $\mathrm{S}$ is the working surface of round specimen, $\mathrm{m}^{2}$; I is the current strength of corrosion, A. Corrosion rate is a function of current corrosion, which was found by:

$$
\mathrm{K}=\mathrm{i}_{\text {corr }} \mathrm{k} \text {, }
$$

where $\mathrm{k}$ is electrochemical equivalent, the numerical value, which for Zinc is 1.22 (for the $\mathrm{Zn} 5 \mathrm{Al}$ alloy) and $0.778 \mathrm{~g} / \mathrm{A} \cdot \mathrm{h}$ is the average of Zinc (1.22) and Aluminum (0.335) for the $\mathrm{Zn} 55 \mathrm{Al}$ alloy, which half of it is made of Aluminum [9].

Generally, accelerated corrosion test assisted to obtain comparative data of the corrosion resistance of alloys that was carried out in accordance with GOST 9.017-86. The tests were conducted on samples of identical size and shape, by the surface preparation, cutting the sample in one direction to the direction of casting. Surface of sample was degreased with acetone, etched with $10 \%$ sodium hydroxide solution at a temperature of $55^{\circ} \mathrm{C}$ for 1 - 2 minutes. Then the samples were washed with the same water, clarified in 30\% nitric acid solution for 2 - 3 minutes and again washed in the distilled water at a temperature of $70^{\circ} \mathrm{C}-90^{\circ} \mathrm{C}$ and were dried.

The corrosion resistance of alloys was evaluated by weighing on an analytical balance with an accuracy more than $0.0001 \mathrm{~g}$ before and after the tests in a solution of $3 \% \mathrm{NaCl}$ before removing corrosion products. Removed corrosion products were produced at a temperature of $95^{\circ} \mathrm{C}-98^{\circ} \mathrm{C}$ and were held for $10-30 \mathrm{~min}$ in a solution contained of $35 \mathrm{ml}$ of $85 \%$ phosphoric acid, $20 \mathrm{~g}$ of chromic anhydride and $945 \mathrm{ml}$ of distilled water. After removing corrosion products, samples were washed in tap water, then in distilled water, were dried in an oven at $105^{\circ} \mathrm{C} \pm 2^{\circ} \mathrm{C}$ for 5 minutes, were placed in a desiccators for 24 hours and then were weighed. Lost corrosion of the sample $(\Delta \mathrm{m})$ in $\mathrm{g} / \mathrm{m}^{2}$ was calculated by the formula:

$$
\Delta \mathrm{m}=\mathrm{m}_{0}-\mathrm{m} / \mathrm{S} \text {, }
$$

where $m_{0}$ is the mass of the sample before the test, $m$ is the mass of the sample after removed corrosion products, $\mathrm{S}$ is the sample surface before the test $\left(\mathrm{m}^{2}\right)$. The corrosion rate $(\mathrm{K})$ in $\mathrm{g} / \mathrm{m}^{2} \cdot \mathrm{h}$ was calculated with the formula:

$$
\mathrm{K}=\Delta \mathrm{m} / \mathrm{t} \cdot \mathrm{S},
$$

where it is the duration of the tests per hour. Character of the corrosion was determined visually. Metallographical studies were carried out by preparing surface, specimens were cut to cylindrical shape with $1 \mathrm{~cm} \times 1 \mathrm{~cm}$ sizes then they were sanded, polished, etched and dried then the test was carried out by AIS2100 Scanning Electron Microscope.

\section{Results and Discussion}

The change in the corrosion potential of $\mathrm{Zn} 5 \mathrm{Al}$ alloy, 
with additive Magnesium in the time in the ambience of $3 \% \mathrm{NaCl}$ electrolytes is shown in Figure 2. It was fixed within an hour, which shows that the first minute of immersion of the alloy in the solution was occurred with a sharp changing potential in the positive region. The concentration of chloride ions in the electrolyte corrosion potential $\left(-\mathrm{E}_{\mathrm{cor}}\right)$ decreases. It indicates that the corrosion resistance of the alloy in a $\mathrm{NaCl}$ ambience has been decreased. Certainly, chemical composition of all alloys mentioned to a sharp changing potential over the time in the positive region, describes dynamic formation of the protective oxide film just ends in 35 minutes from the start of immersion of the electrode into the electrolyte and little depends on their chemical composition. Also the dependence were observed in the $\mathrm{Zn} 55 \mathrm{Al}$ alloy, which has been contained of Magnesium in various concentrations in the studied environments, $0.03 \%, 0.3 \%$ and $3 \%$ solutions of $\mathrm{NaCl}$. The results are listed in Table 1 . However, for Zn55Al alloy with additive Magnesium, the change in the potential of steady state on time shows the formation of protective oxide film in 45 minutes (Table 1).

Studied results of anodic behavior of $\mathrm{Zn} 5 \mathrm{Al}$ and $\mathrm{Zn} 55 \mathrm{Al}$ alloys, with additive Magnesium has been presented in Tables 2 and 3, which indicate that the additive Magne- sium in the ranges of about $0.005-0.1 \mathrm{wt} \%$ Shifts corrosion potentials of $\mathrm{Zn} 5 \mathrm{Al}$ and $\mathrm{Zn} 55 \mathrm{Al}$ source alloys to the positive area. However, increasing the content of Magnesium in the alloys up to $2.0 \mathrm{wt} \%$ shifts $E_{\text {corr }}$ to the negative area, therefore, the visible event due to shift pitting $\left(\mathrm{E}_{\mathrm{pt}}\right)$ and repassive potential $\left(\mathrm{E}_{\mathrm{rp}}\right)$ to the negative direction. The above mentioned features were observed in three studied ambiences.

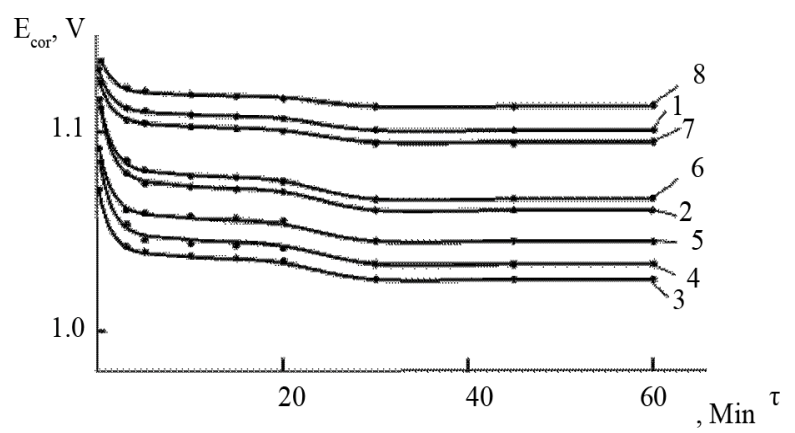

Figure 2. Change in the free potential of corrosion $E_{\text {corr }}(\mathrm{V})$ in time $\tau$ (min) for Zn5Al alloys (1), contained of Magnesium $\left(2\right.$ - 8) in the electrolyte ambience of $3 \% \mathrm{NaCl} . \mathrm{C}_{\mathrm{Mg}}(\mathrm{wt} \%)$ : (2) 0.005 ; (3) 0.01 ; (4) 0.05; (5) 0.1 ; (6) 0.5; (7) 1.0; (8) 2.0.

Table 1. Change in the free potential of corrosion $\left(-E_{\text {free.corr }}, \mathrm{V}\right)$ for $\mathrm{Zn55Al}$ alloy with additive Magnesium in time in the ambience of $\mathrm{NaCl}$ electrolytes.

\begin{tabular}{|c|c|c|c|c|c|c|c|c|c|}
\hline \multirow{2}{*}{ Ambience } & \multirow{2}{*}{$\begin{array}{c}\text { Content of } \mathrm{Mg} \\
\text { in the alloy }(\mathrm{wt} \%)\end{array}$} & \multicolumn{8}{|c|}{ Time (min) } \\
\hline & & $1 / 3$ & $2 / 3$ & 1 & 5 & 15 & 30 & 45 & 60 \\
\hline \multirow{8}{*}{$0.03 \% \mathrm{NaCl}$} & - & 0.992 & 0.991 & 0.990 & 0.988 & 0.982 & 0.975 & 0.972 & 0.970 \\
\hline & 0.005 & 0.944 & 0.943 & 0.938 & 0.935 & 0.928 & 0.924 & 0.920 & 0.920 \\
\hline & 0.01 & 0.968 & 0.965 & 0.961 & 0.959 & 0.956 & 0.953 & 0.950 & 0.950 \\
\hline & 0.05 & 0.975 & 0.972 & 0.970 & 0.965 & 0.961 & 0.958 & 1.953 & 0.956 \\
\hline & 0.1 & 0.988 & 0.986 & 0.985 & 1.980 & 0.977 & 0.975 & 0.972 & 0.972 \\
\hline & 0.5 & 0.997 & 0.996 & 0.994 & 1.990 & 0.986 & 0.982 & 0.980 & 0.980 \\
\hline & 1.0 & 1.026 & 1.023 & 1.020 & 1.014 & 1.009 & 1.006 & 1.005 & 1.005 \\
\hline & 2.0 & 1.055 & 1.053 & 1.052 & 1.050 & 1.044 & 1.036 & 1.033 & 1.003 \\
\hline \multirow{8}{*}{$0.3 \% \mathrm{NaCl}$} & - & 1.022 & 1.022 & 1.020 & 1.046 & 1.009 & 1.002 & 1.001 & 1.000 \\
\hline & 0.005 & 1.014 & 1.012 & 1.009 & 1.002 & 0.999 & 0.996 & 0.995 & 0.995 \\
\hline & 0.01 & 1.030 & 1.029 & 1.027 & 1.023 & 1.021 & 1.019 & 1.018 & 1.018 \\
\hline & 0.05 & 1.042 & 1.040 & 1.037 & 1.033 & 1.029 & 1.026 & 1.024 & 1.024 \\
\hline & 0.1 & 1.063 & 1.060 & 1.057 & 1.052 & 1.048 & 1.063 & 1.040 & 1.040 \\
\hline & 0.5 & 1.078 & 1.077 & 1.074 & 1.070 & 1.067 & 1.065 & 1.063 & 1.063 \\
\hline & 1.0 & 1.092 & 1.091 & 1.088 & 1.085 & 1.080 & 1.076 & 1.075 & 1.075 \\
\hline & 2.0 & 1.098 & 1.097 & 1.095 & 1.091 & 1.087 & 1.082 & 1.080 & 1.080 \\
\hline \multirow{8}{*}{$3 \% \mathrm{NaCl}$} & - & 1.041 & 1.040 & 1.037 & 1.032 & 1.027 & 1.021 & 1.020 & 1.020 \\
\hline & 0.005 & 1.034 & 1.032 & 1.029 & 1.027 & 1.016 & 1.012 & 1.010 & 1.010 \\
\hline & 0.01 & 1.045 & 1.043 & 1.040 & 1.034 & 1.028 & 1.023 & 1.022 & 1.022 \\
\hline & 0.05 & 1.052 & 1.050 & 1.048 & 1.045 & 1.040 & 1.036 & 1.030 & 1.030 \\
\hline & 0.1 & 1.070 & 1.069 & 1.064 & 1.058 & 1.051 & 1.050 & 1.048 & 1.048 \\
\hline & 0.5 & 1.090 & 1.088 & 1.085 & 1.081 & 1.074 & 1.071 & 1.069 & 1.069 \\
\hline & 1.0 & 1.145 & 1.143 & 1.141 & 1.135 & 1.130 & 1.126 & 1.120 & 1.120 \\
\hline & 2.0 & 1.180 & 1.179 & 1.177 & 1.175 & 1.170 & 1.166 & 1.165 & 1.165 \\
\hline
\end{tabular}


Electrolyte and Influence of $\mathrm{Mg}$ on the Structure

Table 2. Electrochemical characteristics of corrosion of the $\mathrm{Zn} 5 \mathrm{Al}$ alloy with additive Magnesium in the ambience of NaCl electrolytes.

\begin{tabular}{|c|c|c|c|c|c|c|c|}
\hline \multirow{3}{*}{ Ambience } & \multirow{3}{*}{$\begin{array}{l}\text { Content of } \mathrm{Mg} \\
\text { in the alloy }(\mathrm{wt} \%)\end{array}$} & \multicolumn{4}{|c|}{ Electrochemical properties } & \multicolumn{2}{|c|}{ Rate of corrosion } \\
\hline & & $-\mathrm{E}_{\text {free.corr. }}$ & $-\mathrm{E}_{\text {corr. }}$ & $-\mathrm{E}_{\mathrm{pa}}$ & $-\mathrm{E}_{\text {rep }}$ & $\mathrm{I}_{\text {corr }} \times 10^{-2}$ & $\mathrm{~K} \times 10^{-3}$ \\
\hline & & \multicolumn{2}{|c|}{ V } & \multicolumn{2}{|c|}{$\mathrm{A} / \mathrm{M}^{2}$} & \multicolumn{2}{|c|}{$\mathrm{g} / \mathrm{m}^{2} \cdot \mathrm{h}$} \\
\hline \multirow{8}{*}{$0.03 \% \mathrm{NaCl}$} & - & 1.050 & 1.060 & 0.915 & 0.930 & 0.102 & 1.24 \\
\hline & 0.005 & 0.998 & 1.000 & 0.845 & 0.922 & 0.031 & 0.38 \\
\hline & 0.01 & 0.969 & 0.972 & 0.825 & 0.958 & 0.026 & 0.32 \\
\hline & 0.05 & 0.977 & 0.980 & 0.855 & 0.962 & 0.033 & 0.40 \\
\hline & 0.1 & 0.958 & 0.987 & 0.870 & 0.970 & 0.034 & 0.41 \\
\hline & 0.5 & 1.005 & 1.010 & 0.895 & 0.982 & 0.041 & 0.50 \\
\hline & 1.0 & 0.020 & 1.025 & 0.910 & 0.988 & 0.059 & 0.72 \\
\hline & 2.0 & 1.055 & 1.060 & 0.925 & 0.995 & 0.068 & 0.83 \\
\hline \multirow{8}{*}{$0.3 \% \mathrm{NaCl}$} & - & 1.070 & 1.080 & 0.935 & 0.950 & 0.105 & 1.28 \\
\hline & 0.005 & 1.014 & 1.022 & 0.880 & 0.942 & 0.033 & 0.40 \\
\hline & 0.01 & 0.976 & 0.983 & 0.905 & 0.963 & 0.029 & 0.35 \\
\hline & 0.05 & 0.980 & 0.990 & 0.912 & 0.968 & 0.036 & 0.44 \\
\hline & 0.1 & 0.997 & 1.000 & 0.924 & 0.974 & 0.037 & 0.45 \\
\hline & 0.5 & 1.018 & 1.017 & 0.930 & 0.980 & 0.045 & 0.55 \\
\hline & 1.0 & 1.040 & 1.045 & 0.935 & 0.985 & 0.064 & 0.78 \\
\hline & 2.0 & 1.075 & 1.075 & 0.940 & 0.990 & 0.076 & 0.93 \\
\hline \multirow{8}{*}{$3 \% \mathrm{NaCl}$} & - & 1.100 & 1.115 & 0.965 & 1.980 & 0.109 & 1.33 \\
\hline & 0.005 & 1.060 & 1.065 & 0.915 & 0.955 & 0.037 & 0.45 \\
\hline & 0.01 & 1.025 & 1.060 & 0.908 & 0.945 & 0.032 & 0.39 \\
\hline & 0.05 & 1.032 & 1.038 & 0.920 & 0.950 & 0.039 & 0.47 \\
\hline & 0.1 & 1.042 & 1.045 & 0.933 & 0.962 & 0.040 & 0.48 \\
\hline & 0.5 & 1.064 & 1.065 & 0.944 & 0.970 & 0.053 & 0.65 \\
\hline & 1.0 & 1.095 & 1.100 & 0.975 & 0.985 & 0.071 & 0.86 \\
\hline & 2.0 & 1.112 & 1.115 & 0.983 & 1.000 & 0.080 & 0.97 \\
\hline
\end{tabular}

Table 3. Electrochemical characteristics of corrosion of the Zn55Al alloy with additive Magnesium in the ambience of NaCl electrolytes.

\begin{tabular}{|c|c|c|c|c|c|c|c|}
\hline \multirow{3}{*}{ Ambience } & \multirow{3}{*}{$\begin{array}{l}\text { Content of } \mathrm{Mg} \text { in the } \\
\text { alloy }(\mathrm{wt} \%)\end{array}$} & \multicolumn{4}{|c|}{ Electrochemical properties } & \multicolumn{2}{|c|}{ Rate of corrosion } \\
\hline & & $-\mathrm{E}_{\text {free.corr. }}$ & $-\mathrm{E}_{\text {corr. }}$ & $-\mathrm{E}_{\mathrm{pa}}$ & $-\mathrm{E}_{\text {rep }}$ & $\mathrm{I}_{\text {corr }} \times 10^{-2}$ & $\mathrm{~K} \times 10^{-3}$ \\
\hline & & \multicolumn{4}{|l|}{ Iree.cort. } & $\mathrm{A} / \mathrm{M}^{2}$ & $\mathrm{~g} / \mathrm{m}^{2} \cdot \mathrm{h}$ \\
\hline \multirow{7}{*}{$0.03 \% \mathrm{NaCl}$} & - & 0.970 & 0.990 & 0.850 & 0.870 & 0.030 & 0.233 \\
\hline & 0.005 & 0.920 & 0.930 & 0.815 & 0.835 & 0.010 & 0.078 \\
\hline & 0.01 & 0.950 & 0.960 & 0.822 & 0.866 & 0.007 & 0.054 \\
\hline & 0.05 & 0.923 & 0.973 & 0.835 & 0.870 & 0.006 & 0.047 \\
\hline & 0.1 & 0.972 & 0.980 & 0.848 & 0.880 & 0.012 & 0.093 \\
\hline & 1.0 & 1.005 & 1.015 & 0.895 & 0.902 & 0.021 & 0.163 \\
\hline & 2.0 & 1.033 & 1.045 & 0.900 & 0.914 & 0.027 & 0.210 \\
\hline \multirow{7}{*}{$0.3 \% \mathrm{NaCl}$} & - & 1.000 & 1.020 & 0.880 & 0.890 & 0.033 & 0.257 \\
\hline & 0.005 & 0.992 & 1.005 & 03820 & 0.860 & 0.012 & 0.093 \\
\hline & 0.01 & 1.018 & 1.023 & 0.843 & 0.880 & 0.008 & 0.062 \\
\hline & 0.05 & 1.024 & 1.035 & 0.860 & 0.875 & 0.007 & 0.054 \\
\hline & 0.1 & 1.040 & 1.055 & 0.875 & 0.885 & 0.014 & 0.109 \\
\hline & 1.0 & 1.075 & 1.081 & 0.952 & 0.965 & 0.024 & 0.187 \\
\hline & 2.0 & 1.080 & 1.090 & 0.960 & 0.976 & 0.031 & 0.241 \\
\hline \multirow{8}{*}{$3 \% \mathrm{NaCl}$} & - & 1.020 & 1.040 & 0.900 & 0.920 & 0.037 & 0.288 \\
\hline & 0.005 & 1.010 & 1.015 & 0.845 & 0.880 & 0.015 & 0.117 \\
\hline & 0.01 & 1.022 & 1.032 & 0.866 & 0.930 & 0.009 & 0.070 \\
\hline & 0.05 & 1.030 & 1.045 & 0.870 & 0.930 & 0.013 & 0.101 \\
\hline & 0.1 & 1.048 & 1.064 & 0.883 & 0.951 & 0.015 & 0.117 \\
\hline & 0.5 & 1.069 & 1.078 & 0.950 & 0.979 & 0.025 & 0.195 \\
\hline & 1.0 & 1.120 & 1.133 & 0.967 & 0.992 & $0 . .030$ & 0.233 \\
\hline & 2.0 & 1.165 & 1.172 & 0.983 & 0.105 & 0.036 & 0.280 \\
\hline
\end{tabular}




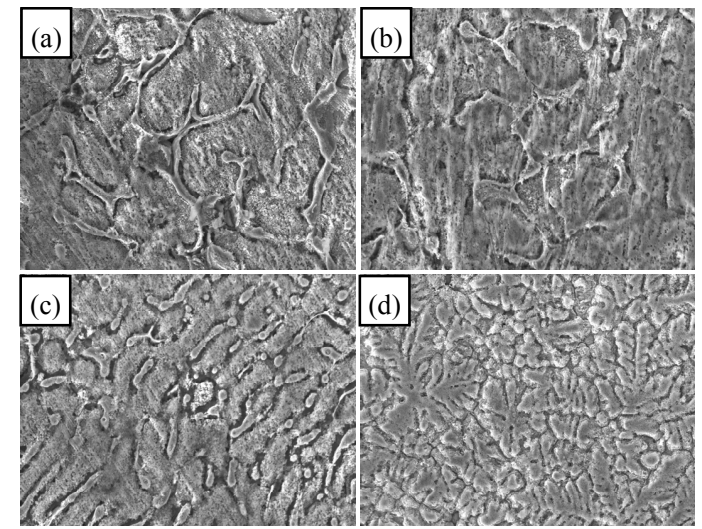

Figure 3. Microstructures $(300 \times)$ of (a) Zn55Al original alloys, (b) with $0.01 \mathrm{Mg}$, (c) Zn5Al original alloys and (d) with $0.01 \mathrm{Mg}$.

According to Tables 2 and 3, when the concentration of chloride ions, corrosion and pitting potentials and the rate of corrosion of $\mathrm{Zn} 5 \mathrm{Al}$ and $\mathrm{Zn} 55 \mathrm{Al}$ alloys increase the additive Magnesium decreases, which indicates a decrease in corrosion resistance of alloys under the influence of chloride ions. Therefore the alloys with additive Magnesium has lower corrosion rates than the original Zinc-Aluminum alloys (Tables 2 and 3), which confirm the gravimetric study. Particularly, the corrosion rate of the original alloy which is defined by this method was $0.40-0.42 \mathrm{~g} / \mathrm{m}^{2}$.hour, and an average of three determinations for the containing of $0.1 \% \mathrm{Mg}$ alloy is $\mathrm{K}=0.49$ $0.51 \mathrm{~g} / \mathrm{m}^{2}$.hour.

According to the phase diagram of $\mathrm{Al}-\mathrm{Zn}-\mathrm{Mg}$ at the ambience temperature [10], the structure of $\mathrm{Zn} 55 \mathrm{Al}$ alloy consists of $\alpha-\mathrm{Al}+\gamma-\mathrm{Zn}$ (Figure 3(a)). When it is alloyed with magnesium, three-phase are formed in amounts of more than $1 \%$ which consist of $\alpha-\mathrm{Al}+\gamma$-Zn phases and $v$-Mg. As an example, Figure 3(b) shows the microstructure of $\mathrm{Zn} 55 \mathrm{Al}$ alloy which contains $0.01 \%$ magnesiums. The composition of phases does not go beyond twophase region which is $\alpha-\mathrm{Al}+\gamma-\mathrm{Zn}$. However, the additive magnesium dissolved in $\alpha$-Al and $\gamma$-Zn solid and greatly refines the structure and transforms it from a needle shape to spherical structure. The role of $\mathrm{Mg}$ is modifying $\mathrm{Zn} 55 \mathrm{Al}$ alloys structure.

The $\mathrm{Zn} 5 \mathrm{Al}$ alloy has different phase ratios of $\alpha-\mathrm{Al}$ and $\gamma$-Zn from Zn55Al alloy, it means that the content of $\gamma-\mathrm{Zn}$ is significantly higher than $\mathrm{Zn} 55 \mathrm{Al}$ alloy. The mechanism of action of magnesium is the same for both alloys. Thus dissolved magnesium does not form new phases, but it plays like a modifier role for the structure (Figures 3(c)-(d)).

Generally, the studied electrochemical research of $\mathrm{Zn} 5 \mathrm{Al}$ and $\mathrm{Zn55Al}$ alloys with additive Magnesium determined a coating corrosion resistant with optimum concentrations of Magnesium about $0.005-0.1 \mathrm{wt} \%$. Corro- sion rates of these alloys are $2-2.5$ times lower than the original alloys and they can be used as an anodic coatings to protect corrosion of steel structures.

\section{Conclusion}

The regularities of changing have been established in the electrochemical characteristics of $\mathrm{Zn} 5 \mathrm{Al}$ and $\mathrm{Zn} 55 \mathrm{Al}$ alloys with additive Magnesium in $\mathrm{NaCl}$ solutions with concentrations of $0.03 \%, 0.3 \%$ and $3 \%$. Particularly, we showed that increasing concentration of chloride ions in the electrolyte contributes to decrease corrosion potential. It has been determined that the potential of the pitting repassiving with increasing concentration of elements in alloys were shifted to the positive area, and with increaseing concentration of chloride ions in the solution, were shifted to the negative area. The corrosion rate of $\mathrm{Zn} 5 \mathrm{Al}$ and $\mathrm{Zn} 55 \mathrm{Al}$ source alloys decrease $2-2.5$ times in order to modify grains by adding Magnesium to $0.1 \%$ which transform needle shape to spherical structure.

\section{Acknowledgements}

This work was supported by department of Material Science and Engineering form Islamic Azad University, Majlesi Branch, Isfahan, Iran.

\section{REFERENCES}

[1] A. M. Shluger, F. F. Azhogin and E. A. Efimov, "Corrosion and Protection of Metals," Metallurgia, Moscow, 1981.

[2] K. Asano and K. Hirano, "Precipitation Process in an AlZn-Mg Alloy," Transactions of the Japan Institute of Metals, Vol. 9, 1968, pp. 24-34.

[3] I. J. Polmear, "Light Alloys-Metallurgy of the Light Metals," St. Edmundsbury Press Ltd., Suffolk, 1995.

[4] A. P. Smiryagin, "Industrial of Non-Ferrous Metals and Alloys," Metallurgia, Moscow, 1981, p. 560.

[5] V. A. Kechin and E. Y. Lublin, "Zinc Alloys," Metallurgia, Moscow, 1986, p. 247.

[6] H. Dafydd, D. A. Worsley and H. N. Mc Murray, "The Kinetics and Mechanism of Cathodic Oxygen Reduction on Zinc and Zinc-Aluminium Alloy Galvanized Coatings," Corrosion Science, Vol. 47, No. 12, 2005, pp. 30063018. doi:10.1016/j.corsci.2005.05.036

[7] I. N. Ganiev and T. M. Umarova, "Corrosion of Double Aluminium Alloys in the Neutral Ambience," Danish, Dushanbe, 2007.

[8] V. Romanov, "Methods of Studying Corrosion of Metals," Metallurgiya, Moscow, 1965, p. 249.

[9] J. M. Kolotyrkin, "Metal and Corrosion," Metallurgia, Moscow, 1985.

[10] N. R. Bochvar and E. S. Kadaner, "The Phase Diagrams of Systems Based on Aluminum and Magnesium Handbook," Nauka, Moscow, 1977. 